\title{
MODELING OF SOIL CO2 EFFLUX DURING WATER TABLE FLUCTUATION BASED ON IN SITU MEASURED DATA FROM A SEDGE-GRASS MARSH
}

\author{
PAVELKA, M. - DARENOVA, E. ${ }^{*}$ - DUSEK, J. \\ Global Change Research Institute CAS, v.v.i., Belidla 986/4a, Brno, Czech Republic \\ *Corresponding author \\ email: darenova.e@czechglobe.cz; tel: +420-511-192-242 \\ (Received $19^{\text {th }}$ Feb 2016; accepted 20 $0^{\text {th }}$ May 2016)
}

\begin{abstract}
Soils of wetland ecosystems serve as a huge storage of organic carbon. Its decomposition and consequent release of $\mathrm{CO}_{2}$ into the atmosphere is highly affected by soil hydrology, and this release of $\mathrm{CO}_{2}$ may severely increase during future climate change. The aim of this study was to describe the immediate response of soil $\mathrm{CO}_{2}$ efflux to temperature and changes in water level. Soil $\mathrm{CO}_{2}$ efflux from a marsh, temperature and the water table were continuously measured in situ during a gradual decrease of the water table and its consequent rapid increase after heavy rain. $\mathrm{CO}_{2}$ efflux fluctuated as it followed diurnal changes in temperature. However, it showed an increasing trend as the water table decreased. After the rain, the water table rose above the soil surface and soil $\mathrm{CO}_{2}$ efflux dropped fast to nearly zero. A simple model based on soil temperature and water table level was created to estimate soil $\mathrm{CO}_{2}$ efflux. There was far better agreement between this model and measured data than with the widely used model based only on temperature. The results showed the importance of including the soil water conditions in models for estimating soil $\mathrm{CO}_{2}$ efflux at sites with a high water table level.
\end{abstract}

Keywords: Carex acuta, fen, soil chamber, soil respiration, wetland

\section{Introduction}

Carbon dioxide efflux from soil remains the second largest carbon flux in most ecosystems after photosynthesis (Kuzyakov, 2006) and it accounts for ca 60-90\% of total ecosystem respiration (Goulden et al., 1996, Longdoz et al., 2000). Therefore, quantification of soil $\mathrm{CO}_{2}$ efflux is important for understanding the carbon dynamics of terrestrial ecosystems and predicting possible future scenarios.

Soil respiration consists of autotrophic and heterotrophic components (Kuzyakov, 2006). The first comprises the respiration of plant roots and is a major source of $\mathrm{CO}_{2}$ loss in plants, while heterotrophic respiration occurs among soil microorganis ms.

$\mathrm{CO}_{2}$ efflux from soil results from autotrophic respiration by live roots and heterotrophic respiration is caused mainly by the decomposition of organic matter by microorganisms (Kuzyakov, 2006). Obtaining accurate estimates of $\mathrm{CO}_{2}$ efflux from the soil to the atmosphere represents a significant challenge, it is particularly difficult to separate the autotrophic and heterotrophic components without disturbing the soil system (Kutsch et al., 2009).

Both the rate of the $\mathrm{CO}_{2}$ efflux from the soil and the immediate responses of $\mathrm{CO}_{2}$ efflux to changing conditions vary in different types of ecosystems. Suitable conditions are necessary for the biogeochemical processes involved in producing $\mathrm{CO}_{2}$. The crucial factor for these, mostly aerobic, processes is temperature and the availability of water and nutrients. In wetland ecosystems a crucial factor is the level of the water related to the soil surface. 
Generally, the biggest portion of soil respiration takes place in the top soil layers because of root presence, higher soil temperature and oxygen content compared to lower horizons (Sierra and Renault, 1998; Tufekcioglu et al., 1999; Lafleur et al., 2005). At wetlands, moreover, these top horizons get aerated when water table decreases while lower horizons remain often water saturated. The water table and its possible fluctuation determine whether conditions are anoxic or anaerobic and thus they also determine the prevailing biogeochemical processes in wetland soils and in the whole wetland ecosystem (Reddy and DeLaune, 2008). Therefore, the water table level significantly affects $\mathrm{CO}_{2}$ exchange between the ecosystem and the atmosphere (Dusek et al., 2009; Jimenez et al., 2012), and thus also affects the gross ecosystem production, including the gross radiation use efficiency (Dusek et al., 2012a).

The relationship between $\mathrm{CO}_{2}$ efflux and temperature is quite well known and has been presented in previous studies (Lloyd and Taylor, 1994; Pavelka et al., 2007; Subke and Bahn, 2010). However, the effect of water table fluctuations on $\mathrm{CO}_{2}$ efflux has been studied in previous studies. Mostly a decrease of soil respiration was observed with increasing water table (Oechel et al., 1998; Yang et al., 2013) as a result of limited oxygen diffusion in water filled pores (Chamindu Deepagoda and Elberling, 2015). However, the possible synergic effect with other factors (temperature, nutrient availability) causes different responses to unitary water table changes and makes it difficult to understand this phenomena.

$\mathrm{CO}_{2}$ efflux from the soil or from plant stands can be measured using different methods (Livingston and Hutchinson, 1995; Alm et al., 2007). One of the most commonly used methods for $\mathrm{CO}_{2}$ flux investigation is the eddy-covariance technique (Baldocchi, 2003; Aubinet et al., 2012). This method measures $\mathrm{CO}_{2}$ flux over a certain area, footprint, where the size and shape of this footprint depends on the height of measuring system and on the direction and velocity of the prevailing winds (Aubinet et al., 2012). The eddy-covariance technique cannot distinguish between $\mathrm{CO}_{2}$ fluxes from different parts of the ecosystem and cannot describe flux variation in space. For a detailed focus on $\mathrm{CO}_{2}$ efflux from the soil it is better to use the chamber method, which is precise enough for soil $\mathrm{CO}_{2}$ efflux measurement (Livingston and Hutchinson, 1995; Pumpanen et al., 2004; Reth et al., 2005) and is capable of recording the responses to changing conditions (e.g. temperature and water table fluctuations).

The aims of this study were to mathematically describe the immediate response of soil $\mathrm{CO}_{2}$ efflux to soil temperature and changes in water table level and to compare this model with the model based only on soil temperature. As soil temperature is a driving factor of soil $\mathrm{CO}_{2}$ efflux only till a certain percentage of soil water content, we aimed to determine what was the level of water table when soil temperature stops affecting soil $\mathrm{CO}_{2}$ efflux. At these level of water table soil $\mathrm{CO}_{2}$ efflux also displays a rapid decline. Therefore, determination of this level of water table and of the response of soil $\mathrm{CO}_{2}$ efflux is crucial for soil $\mathrm{CO}_{2}$ efflux models at wetland sites.

The data used in this study was measured during a continuous measurement campaign, which was carried out in a sedge-grass marsh under real conditions and without any manipulation of the conditions. 


\section{Materials and methods}

\section{Site description}

The monitored sedge-grass marsh is a 1.5 ha part of the large "Wet Meadows" wetland complex, situated near the town of Trebon in South Bohemia, Czech Republic, close to an ancient man-made lake called Rozmberk. This ancient lake was created in the Middle Ages for fish production and for agricultural production in the local catchment. Man-made lakes, generally referred to as fishponds, were created in places where originally wet meadows and wetlands occurred. The sedge-grass marsh (location of the meteorological station is $49^{\circ} 01^{\prime} 29^{\prime \prime} \mathrm{N}, 14^{\circ} 46^{\prime} 13^{\prime \prime} \mathrm{E}$ ) is a flat area at an altitude of $426.5 \mathrm{~m}$ above sea level. The mean annual air temperature and mean annual precipitation, for a 35-year period between 1977 and 2011, were $7.6{ }^{\circ} \mathrm{C}$ and $614 \mathrm{~mm}$, respectively (Dusek et al., 2012b). For previous ecological studies that focused on the "Wet Meadows" sedge-grass marsh site see Jenik and Kvet (1983) and Kvet et al. (2002). The water table mostly fluctuates between $-0.2 \mathrm{~m}$ and $1.0 \mathrm{~m}$ throughout the year. Most frequently the water table is situated at about $-0.1 \mathrm{~m}$. In some years, spring or summer floods occurred. These floods are a consequence of snow melting or heavy summer rains. The sedge part of the wetland complex was mown once a year until the 1950's. The resulting vegetation was formed mainly by tall sedges (Carex acuta, Carex vesicaria) and hygrophytic grasses (especially Calamagrostis canescens) (Holubickova, 1959; Gazda, 1983; Prach, 1993; Prach and Soukupova, 2002; Prach, 2008). During the last 50 years, after cessation of mowing, a distinct stand pattern of hummocks and hollows has developed. The hummocks are formed by tussocks of Carex acuta.

\section{Soil properties}

Soils in the sedge-grass marsh can be classified as histosols (Reddy and DeLaune, 2008) with a high amount of organic matter in the upper soil layers. Formation of these soils is based on sedimentation processes during the post glacial period when lower layers of the soil profile were created. The lower profile consists of sand and clay with accessory organic matter. The upper layer of soil has been formed over the last hundred years as a result of the accumulation of partially decomposed organic matter. These layers contained more organic matter than the lower layers, with slight stripes of sand, clay or gravel. The thickness of the organic layers created by peat vary from $0.5 \mathrm{~m}$ to several meters (Jenik et al., 2002). Basic chemical characteristics of the soil are summarized in Table 1. The bulk density of the 0 to $0.3 \mathrm{~m}$ layer is between 0.30 and $0.40 \mathrm{~g} \mathrm{~cm}^{-3}$ and it contains on average about $21.6 \%$ carbon. Due to the constantly high water table levels over the last hundred years, upper organic layers were not decomposed and remained in the site.

\section{Soil $\mathrm{CO}_{2}$ efflux, soil temperature and water table depth measurements}

Measurement of soil $\mathrm{CO}_{2}$ efflux was carried out using a manual portable and an automated gasometrical systems.

Manual measurements on 30 positions within $40 \mathrm{~m}$ around the automated chamber were taken on 21 and 22 September 2010 in the morning hours using portable closed system Li6200 (Li-Cor, Lincoln, NE, USA). The system consisted of an infrared gas analyzer (Li6250, Li-Cor, USA), a control unit (Li6200, Li-Cor, USA) and an opaque soil chamber developed at the Global Climate Change Institute CAS. On each position $\mathrm{CO}_{2}$ efflux was measured from collars inserted about $3 \mathrm{~cm}$ deep into the soil one week 
before the first measurement. Next to each collar soil temperature. During each measurement, soil temperature at $1.5 \mathrm{~cm}$ (penetrate thermometer, Roth, GE) and soil moisture in the 0-6 cm profile (ThetaProbe ML2x, Delta-T Devices, UK) were measured at three points located $5 \mathrm{~cm}$ outside the collar, with the mean values being used for subsequent analysis.

Table 1. Chemical characteristics of the organic soil in the sedge-grass marsh community of the Wet Meadows at 0-30 cm depth of soil profile. Analyses were performed by the Agro-La Comp. Laboratories at Jindrichuv Hradec.

\begin{tabular}{lcc}
\hline Parameter & mean & SD \\
\hline $\mathrm{pH}\left(\mathrm{CaCl}_{2}\right)$ & 4.8 & 0.1 \\
Potassium [mg/kg] & 144.8 & 37.1 \\
Magnesium [mg/kg] & 395.8 & 32.1 \\
Calcium [mg/kg] & 2692.0 & 227.0 \\
Dry matter [\%] & 42.3 & 4.9 \\
Total phosphorus [\%] & 0.2 & 0.0 \\
Total nitrogen [\%] & 0.9 & 0.1 \\
Ash [\%] & 71.4 & 2.5 \\
\hline
\end{tabular}

Automated continuous measurements were done using a system ACSEM (developed at the Global Change Research Institute CAS) between 20 and 26 September 2010. This system consisted of a chamber with an automatic closing function and an EGM-3 analyzer (PP-System, United Kingdom). The chamber was controlled by a DL3000 logger (Delta-T Ltd, UK), which also stored the measured data. The chamber was installed in a hollow (free space between hummocks of Carex acuta). The selected hollow was without any vegetation cover. The possibility for aboveground plant organs to contribute to $\mathrm{CO}_{2}$ efflux was excluded. Soil temperature measurements at depths of $0.5,1.5,3,5$ and $10 \mathrm{~cm}$ were made near the chamber by PT 1000 platinum thermometers (HIT Uherske Hradiste, Czech Republic). The water table level was continuously measured by a LP 307 hydrostatic pressure sensor (BD Sensors, Czech Republic). $\mathrm{CO}_{2}$ efflux from the soil and soil temperatures were measured at $15 \mathrm{~min}$ intervals, while the water table level was measured at $30 \mathrm{~min}$ intervals.

\section{Data analysis and calculations}

Soil $\mathrm{CO}_{2}$ efflux $\left(\mathrm{R}_{\mathrm{S}}\right)$ was plotted against soil temperature $\left(\mathrm{T}_{\mathrm{S}}\right)$ and this was fit by an exponential regression curve with the regression equation:

$$
R_{S}=\beta \cdot e^{\alpha \cdot T_{S}}
$$

where $\alpha$ and $\beta$ are the regression coefficients. $Q_{10}$ (the proportional change in $\mathrm{CO}_{2}$ efflux caused by a $10{ }^{\circ} \mathrm{C}$ increase in temperature) was calculated as:

$$
Q_{10}=e^{10 \cdot \alpha}
$$


where $\alpha$ is the regression coefficient obtained from Equation 1. Then, $\mathrm{CO}_{2}$ efflux was normalized for the temperature of $10{ }^{\circ} \mathrm{C}\left(\mathrm{R}_{10}\right)$ according to equation:

$$
R_{10}=\frac{R_{S}}{Q_{10}{ }^{\frac{T_{S}-10}{10}}}
$$

To estimate soil $\mathrm{CO}_{2}$ efflux from measured parameters we used the reversed equation:

$$
R_{m}=\frac{R_{10}}{Q_{10}^{\frac{10-T_{S}}{10}}}
$$

For fitting the $\mathrm{R}_{10}$ data and the depth of the water table we used the program TableCurve (Systat, USA), the correlation statistics were provided in the analysis software SigmaPlot 11.0 (Systat, USA).

\section{Statistical analyses}

The program TableCurve 2D (Systat Software, San Jose, CA, USA) was used to find the relationship between $\mathrm{R}_{10}$ and the water table and to fit the curve. The correlation between measured and modelled soil $\mathrm{CO}_{2}$ efflux was tested by using the Pearson Correlation test in SigmaPlot 11.0 (Systat Software, San Jose, CA, USA). Moreover, a Taylor diagram (Taylor, 2001) was applied to compare measured and modelled soil $\mathrm{CO}_{2}$ efflux data. This diagram was implemented in $\mathrm{R}$ statistical software ( $\mathrm{R}$ Development Core Team 2011).

\section{Results}

\section{Overall conditions in September}

The mean monthly air temperature in September 2010 was $11.2{ }^{\circ} \mathrm{C}$, which was lower than the long-term air temperature for this month $\left(12.2^{\circ} \mathrm{C}\right.$ for the period $\left.1977-2010\right)$. The air temperature in September 2010 ranged from 7 to $14{ }^{\circ} \mathrm{C}$ and decreased in the first half of the month and again in the middle of month (Figure 1A). Soil temperature ranged between $10.1^{\circ} \mathrm{C}$ and $10.8^{\circ} \mathrm{C}$.

The monthly sum of precipitation was $61.6 \mathrm{~mm}$, which was about $13 \%$ higher than the long-term mean (53.4 mm for period 1977-2010). During September 2010, there were eight rain events with more than $3 \mathrm{~mm}$ of precipitation recorded. The water table fluctuated according to precipitation and high increase in water table were recorded during rainy days (gray area around solid black line in the Figure $1 B$ ). The water table fluctuated between $8 \mathrm{~cm}$ below the soil surface and $5 \mathrm{~cm}$ above the soil surface. Precipitation in the middle of the month $(12.6 \mathrm{~mm})$ raised the water table daily average from $-2 \mathrm{~cm}$ below the soil surface to about $4 \mathrm{~cm}$ above the soil surface. After that the water table slowly decreased to a minimum daily average value of $-8 \mathrm{~cm}$ below the soil surface. The water table remained at this minimum for one day and after that it increased rapidly to $5 \mathrm{~cm}$ above the soil surface. This increase in water table was caused by heavy rain on 26 September when the daily sum amounted to $19 \mathrm{~mm}$. During the 
following three days precipitation ranged from between 4 and $8 \mathrm{~mm}$ per day and the water table remained stable at $5 \mathrm{~cm}$ above the soil surface.

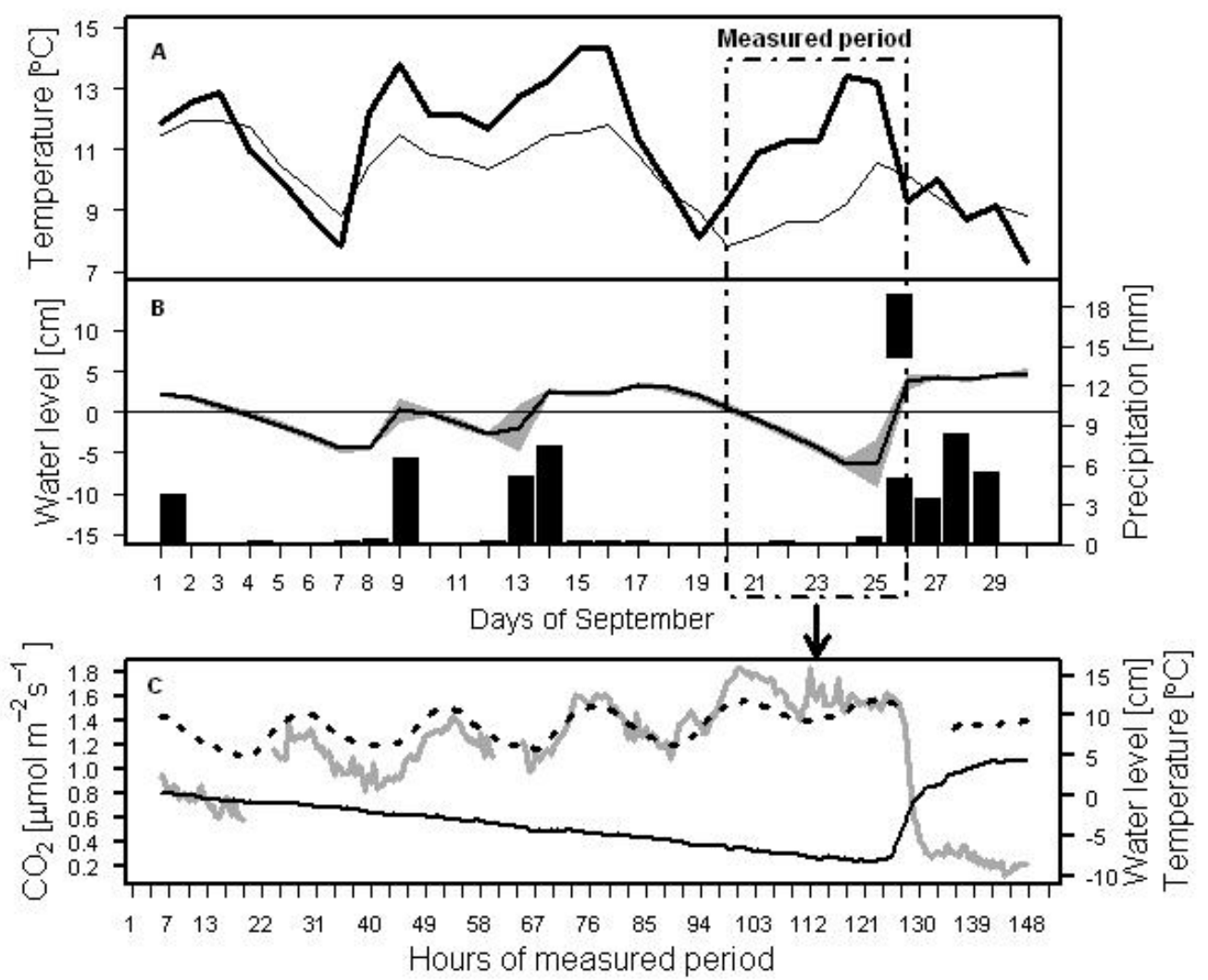

Figure 1. Daily courses of studied parameters. A-Daily means of air temperatures at $2 \mathrm{~m}$ height (thick line); daily means of soil surface temperatures (thin line). B-daily sums of precipitation (bars) in September together with changing water level (black line). Variability of water level, shown as gray area around solid black line. $\mathrm{C}$ - Soil $\mathrm{CO}_{2}$ efflux (gray line); soil temperature (dashed line); water level (solid line). Measured period is marked in the Figures A and $B$ as a dashed box.

\section{Detailed conditions during experimental period}

The experimental period was set in the end of September 2010. During this period there was a controlled discharge of the lake, therefore the water table decreased slowly until 25 September when it started raining (Figure 1C). During this period the water table gradually decreased from $0.4 \mathrm{~cm}$ above the soil surface to $-8.0 \mathrm{~cm}$ below the soil surface. After the rain the water table increased up to $4.2 \mathrm{~cm}$ above the soil surface and measurements had to be stopped on 26 September due to possible damage to the measuring system.

The highest soil temperature during $\mathrm{CO}_{2}$ efflux measurement was at a depth of $0 \mathrm{~cm}$ with an amplitude of $9.3^{\circ} \mathrm{C}$, the lowest soil temperature was recorded at a depth of $10 \mathrm{~cm}$ with an amplitude of only $1.1{ }^{\circ} \mathrm{C}$. In the daytime, the highest temperature was at the soil surface $(0 \mathrm{~cm})$ and temperature decreased with soil depth. At night this was reversed. Soil temperature minima and maxima at depths of $1.5,3,5$ and $10 \mathrm{~cm}$ lagged behind the temperature of the soil surface by $0.9,1.3,2.2$ and $3.2 \mathrm{~h}$ for minima, and 1.9, 2.9, 4.1 and 
$6.8 \mathrm{~h}$ for maxima, respectively. After the rain, fluctuations in of soil temperature were reduced and it was difficult to clearly determine the minimum and maximum.

\section{Soil $\mathrm{CO}_{2}$ efflux}

During manual measurements of soil $\mathrm{CO}_{2}$ efflux, mean soil water content at 30 positions reached $88.1 \pm 9.7 \%$. Soil $\mathrm{CO}_{2}$ efflux was $1.40 \pm 0.92 \mu \mathrm{mol} \mathrm{m}^{-2} \mathrm{~s}^{-1}$ corresponding to the mean soil temperature $9.2 \pm 0.9^{\circ} \mathrm{C}$ on 21 September, and $1.47 \pm 0.84 \mu \mathrm{mol} \mathrm{m}^{-2} \mathrm{~s}^{-1}$ corresponding to the mean soil temperature $10.7 \pm 10.3{ }^{\circ} \mathrm{C}$ on 22 September.

From 20 to 25 September, soil $\mathrm{CO}_{2}$ efflux from the automated chamber followed the diurnal pattern of changes in soil temperature, with maxima in early afternoon and minima at night. However, the relationship between temperature and soil $\mathrm{CO}_{2}$ efflux was not so strong $\left(\mathrm{R}^{2}=0.59\right)$. This can be attributed to the gradually decreasing water table accompanied with the increasing trend of $\mathrm{CO}_{2}$ efflux (Figure 1C). After heavy rain on 25 September and a rapid increase in the water table, soil $\mathrm{CO}_{2}$ efflux rapidly dropped to about $0.2 \mu \mathrm{mol} \mathrm{m} \mathrm{m}^{-2}$ despite the temperature remaining at the same level. The most remarkable decrease in $\mathrm{CO}_{2}$ efflux occurred when the water table was between -3 and $+3 \mathrm{~cm}$.

The dependence of soil $\mathrm{CO}_{2}$ efflux on soil temperature was the strongest for temperature measured at a depth of $1.5 \mathrm{~cm}$, in accordance with the methodology presented by Pavelka et al. (2007). The $\mathrm{Q}_{10}$ value for $\mathrm{CO}_{2}$ efflux normalization using this temperature was 2.2. $\mathrm{R}_{10}$ was calculated for every measurement using equitation (Eq. 3). Calculated $\mathrm{R}_{10}$ was plotted against the depth of the water table (Figure 2). The data were then fitted with a modified exponential curve:

$$
y=a \cdot e^{-0.5 \cdot\left|\frac{D_{W T}-(-b)}{c}\right|^{d}}
$$

where $a=1.54, b=10.34, c=10.27, d=3.96$ and $D_{W T}$ is the depth of the water table. This relationship was incorporated into Equation 4 instead of parameter $R_{10}$. Then, the modeled soil $\mathrm{CO}_{2}\left(\mathrm{R}_{\mathrm{m}}\right)$ was calculated as:

$$
R_{m}=\frac{R_{10}}{Q_{10} \frac{10-T_{s}}{10}}=\frac{1.54 \cdot e^{-0.5 \cdot\left|\frac{D_{W T}+10.34}{10.27}\right|^{3.96}}}{Q_{10} \frac{10-T_{s}}{10}}
$$

When soil $\mathrm{CO}_{2}$ efflux was modeled using only measured temperature (Equation 4), there was not good agreement with measured data. Although the Pearson Correlation test confirmed significant correlation between measured and modelled data $(\mathrm{p}<0.001)$, the $\mathrm{R}^{2}$ value reached only 0.32 (Figure 3, Figure 4). Modeled soil $\mathrm{CO}_{2}$ efflux did not show any increasing trend during the decreasing of the water table level. Moreover, this model estimated high $\mathrm{CO}_{2}$ efflux after the rain (about $1.3 \mu \mathrm{mol} \mathrm{m}^{-2} \mathrm{~s}^{-1}$ ) in comparison with measured data.

When the depth of the water table was included into the simple model, modeled soil $\mathrm{CO}_{2}$ efflux was in better agreement with measured data and $\mathrm{R}^{2}$ increased to 0.95 (Figure 4, Figure 5). 


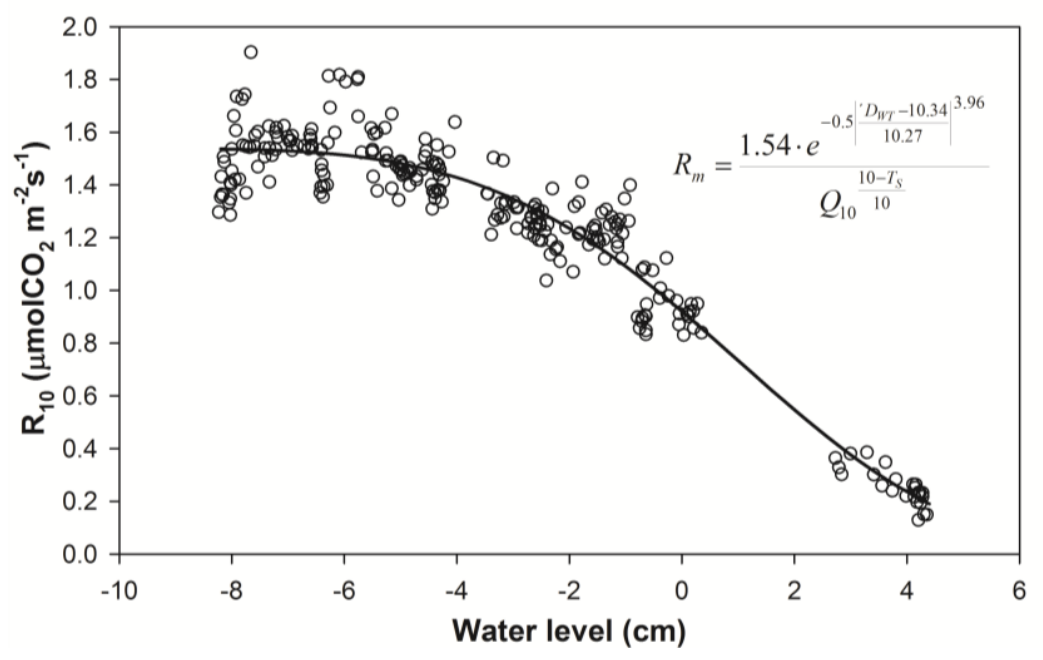

Figure 2. Dependence of normalized $\mathrm{CO}_{2}$ soil efflux $\left(R_{10}\right)$ on water level fluctuations.

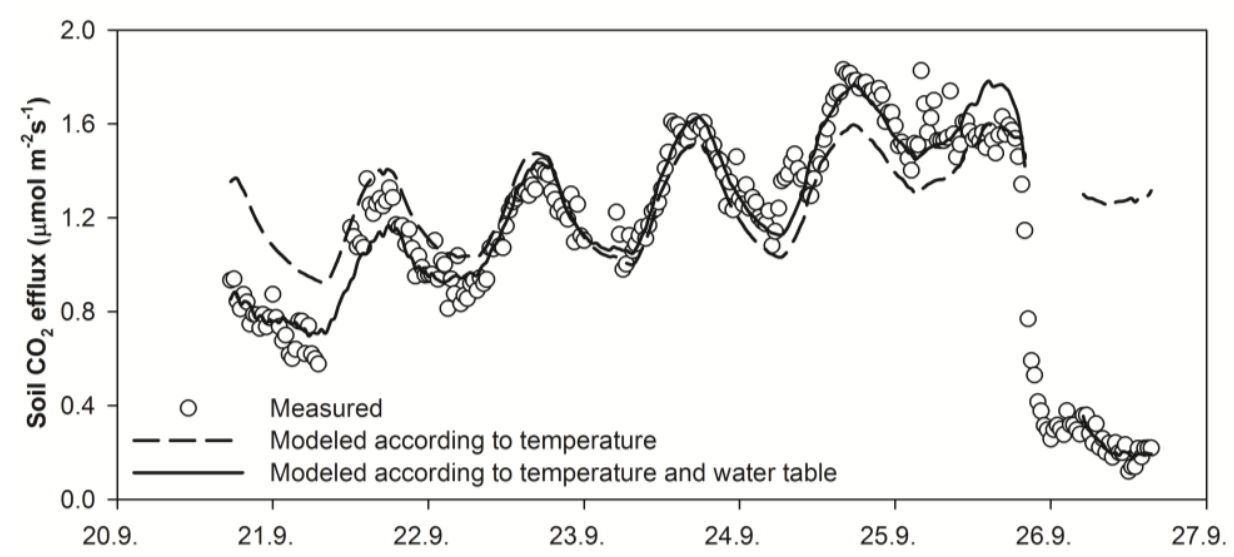

Figure 3. Soil $\mathrm{CO}_{2}$ efflux measured, modeled according to the soil temperature (Equation 4) and modeled according to the soil temperature and the water level (see Equation 6).
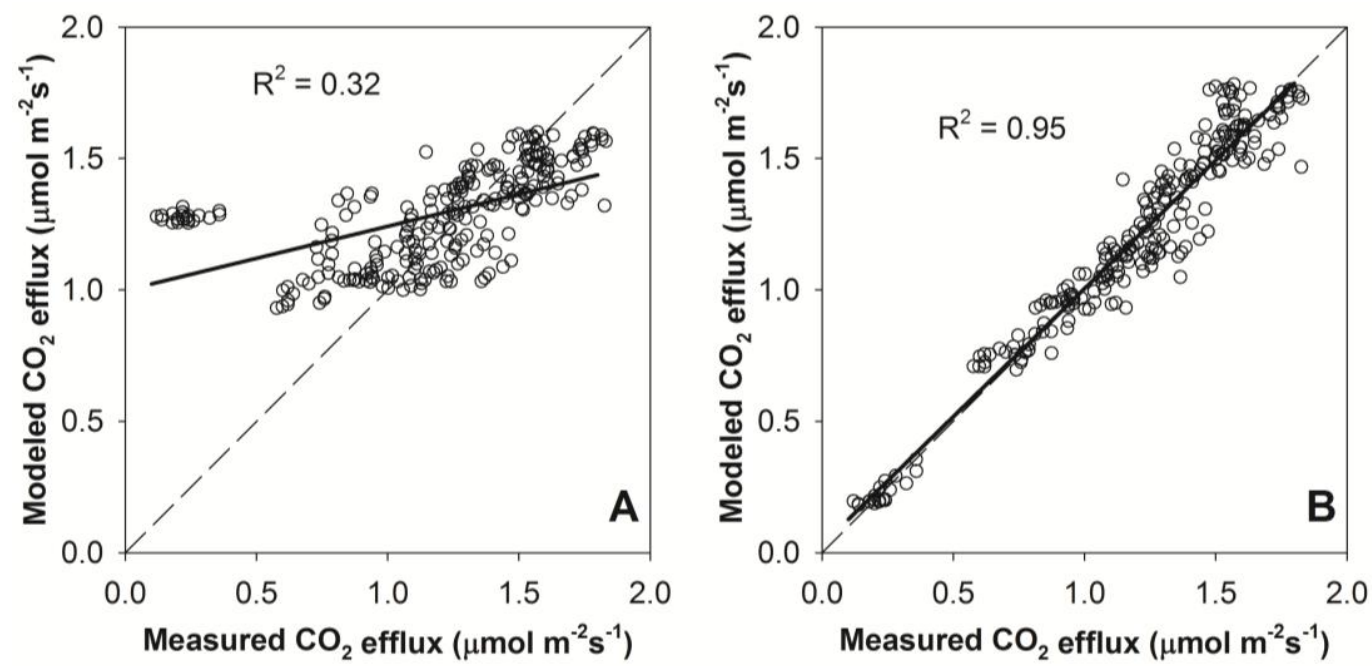

Figure 4. Relationship between modeled soil $\mathrm{CO}_{2}$ efflux and measured $\mathrm{CO}_{2}$ efflux. A-model based only on soil temperature, $B$ - model based on soil temperature and water level. 


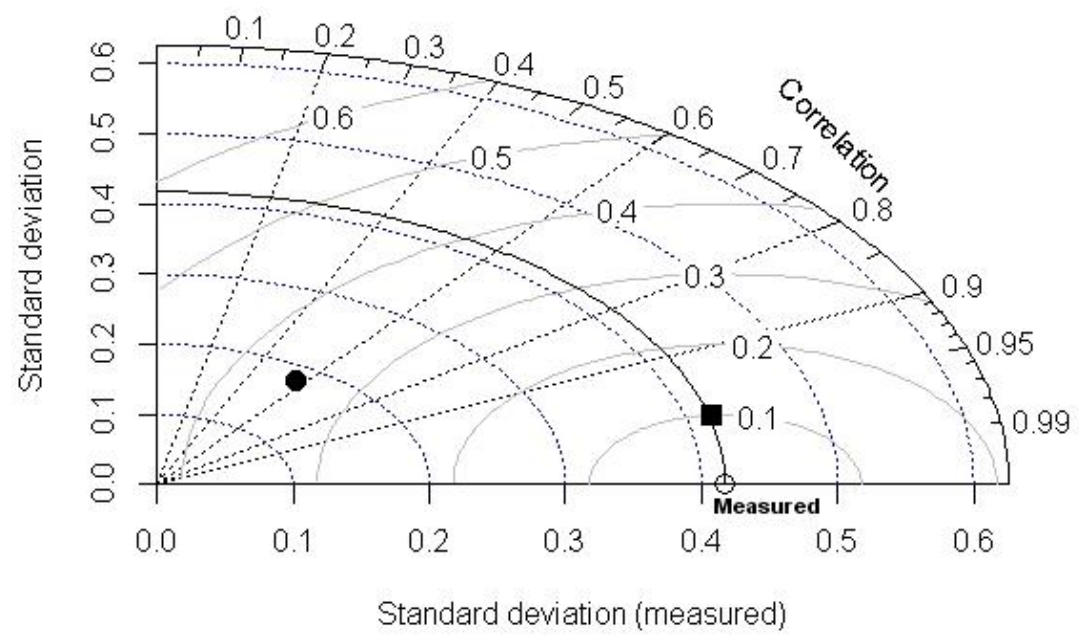

Figure 5. Taylor diagram comparing the relationships between measured soil $\mathrm{CO}_{2}$ efflux (empty circle on $x$ axis labeled as "Measured") and soil $\mathrm{CO}_{2}$ efflux modeled using soil temperature (filled black circle) and modeled using both soil temperature and water table fluctuation (filled black square).

The similarity between models is presented in the Taylor diagram (Figure 5), which is quantified in terms of their correlation, their centered root-mean-square difference (RMS) and the amplitude of their variations (Taylor, 2011). From this graph, differences between two soil $\mathrm{CO}_{2}$ efflux models and measured data (open circle on the $\mathrm{x}$ axis) are evident. The model based only on soil temperature (filled black circle) has a lower variation (0.18), presented as standard deviation, than measured data (0.41). Data variation of the model based on both soil temperature and water table fluctuations is very close to the variation of measured data. The correlation coefficients for the relationships between modeled data and measured data were 0.564 for the model with soil temperature and 0.972 for the model with soil temperature and water table fluctuations, respectively. The model based on both soil temperature and water table fluctuations also had a lower RMS value (0.1) than the model based only on soil temperature.

\section{Discussion}

Maxima and minima soil temperatures at depths of 1.5, 3, 5 and $10 \mathrm{~cm}$ lagged behind measured temperatures at the soil surface. This time lag increased with increasing depth, while the temperature amplitude decreased. This has been observed in other studies (Pavelka et al., 2007; Phillips et al., 2011). A time lag between soil $\mathrm{CO}_{2}$ efflux and measured soil temperature has also been described in previous studies (e.g. Reichstein et al., 2005). Riveros-Iregui et al. (2007) or Phillips et al. (2010) investigated the effect of soil moisture on this hysteresis. The authors found that the hysteresis was lower under dry conditions than when the soil was wet. It can be explained by the effect of soil water content on two important soil processes: $\mathrm{CO}_{2}$ diffusivity and thermal diffusivity, which decrease with increasing soil moisture (Jassal et al., 2005; Wang and Bou-Zeid, 2012). Therefore, soils with high water content get less warm and lower layers do not contribute much to the soil surface $\mathrm{CO}_{2}$ efflux. 
Soil $\mathrm{CO}_{2}$ efflux from the automated chamber ranged from 0.6 to $1.8 \mu \mathrm{mol} \mathrm{m} \mathrm{m}^{-2} \mathrm{~s}^{-1}$ between 21 and 25 September when water table was below soil surface. Mean values of soil $\mathrm{CO}_{2}$ efflux measured by the portable system on 30 positions (1.40 and 1.470 .6 to $1.8 \mu \mathrm{mol} \mathrm{m} \mathrm{m}^{-2}$ ) fitted to this range. This supported our assumption that the automated chamber was on a representative position.

Temperature sensitivity of $\mathrm{CO}_{2}$ efflux (parameter $\mathrm{Q}_{10}$ ) was estimated based on the temperature measured at the depth of $1.5 \mathrm{~cm}$ (according to the methodology of Pavelka et al. (2007)). $\mathrm{Q}_{10}$ was equal to 2.2, which is in the range (1.4-3.4) of values expected for wetland or peatland soils (Bonnett et al., 2006; Vicca et al., 2009; Inglett et al., 2012). This $\mathrm{Q}_{10}$ value was used to normalize soil $\mathrm{CO}_{2}$ efflux for $10{ }^{\circ} \mathrm{C}\left(\mathrm{R}_{10}\right) \cdot \mathrm{R}_{10}$ negatively correlated with the depth of the water table. Few studies have described a weak relationship between $\mathrm{CO}_{2}$ efflux and the water table position (Lafleur et al., 2005; Bubier et al., 1998). However, the majority of previous studies observed a strong relationship (e.g. Jaatinen et al., 2008; Lloyd, 2006; Vicca et al., 2009) similar to the one observed in this investigation.

In our study, the steepest decline in soil $\mathrm{CO}_{2}$ efflux was observed with water table decrease to $3 \mathrm{~cm}$ below the soil surface. Other decrease of water table had much smaller effect on soil $\mathrm{CO}_{2}$ efflux. This confirm that the biggest portion of $\mathrm{CO}_{2}$ efflux production is placed in the top soil layer which is in accordance with other studies. In situ, the increase in $\mathrm{CO}_{2}$ emission has mostly been seen only with a lowering to a certain depth, between 10 and $30 \mathrm{~cm}$ depending on the study, with no further increase with a further lowering (Silvola et al., 1996; Chimner and Cooper, 2003; Jaatinen et al., 2008). Chimner and Cooper (2003) suggested the lack of easily oxidized labile $C$ in the deeper soil layers as a reason for this pattern. This is supported by the results of Hogg et al. (1992) that in drained samples in vitro the release of $\mathrm{CO}_{2}$ was about 10 times greater from $0-10 \mathrm{~cm}$ peat layer than from $30-40 \mathrm{~cm}$ layer, which they attributed to the relatively large pool of non-structural carbohydrates in surface samples, deriving from recently dead plant biomass.

The $\mathrm{CO}_{2}$ efflux model based on temperature (Equation 4) is a method that is commonly used to estimate the amount of $\mathrm{CO}_{2}$ released from ecosystems (Davidson et al., 2006). This method is suitable for situations where the soil temperature is the variable driving the seasonal dynamics of $\mathrm{CO}_{2}$ efflux. However, the influence of temperature can decrease when soil water content is very low or very high (temperature and $\mathrm{CO}_{2}$ efflux can even become decoupled; $\mathrm{Xu}$ et al., 2004). The latter case is common for wetland or peatland ecosystems.

Soil saturation by water results in the decline in activity of the soil processes dependent on the availability of oxygen. Just, the fast submerging of whole soil profile almost immediately switches internal soil conditions from aerobic to anaerobic processes. Therefore, we can observe suppression of aerobic decomposition of organic matter and its alternation with slower anaerobic decomposition (Inglett et al., 2005). This becomes evident as methane $\left(\mathrm{CH}_{4}\right)$ is produced and released into the atmosphere (Altor and Mitsch, 2008; Knorr et al., 2008).

Although this switch can have also some time lag as in case of soil temperature changes, submerging of soil profile is accompanied by gradual water table rise up to or above soil surface together with saturation of the soil surface by water from precipitation. The gradual rise of the interstitial water table displaces air in soil pores and usually decreases soil temperature mainly in surfaces layers. Submersion of the whole soil profile changes markedly physical properties of soils. Rates of gas transport 
in submerged soils are greatly reduced relatively to that in air. The structure of soil reduces the cross-sectional area available for gas flow and increases the tortuosity. Transfer coefficients within soil environments may be $10^{2}$ to $10^{5}$ times lower than in the atmosphere environments (Matson and Harriss, 1995). According to Greenwood (1961) diffusion of gases in water-filled soil pores is in average 10,000 times slower than diffusion in gas-filled soil pores. When a soil is submerged, gas exchange between soil and air is drastically curtails. After submersion the atmospheric gases can enter to the soil profile only by molecular diffusion in the interstitial water (Ponnamperuma, 1972).

The depth of the water table also has an effect on the microbial community. Jaatinen et al. (2008) observed an increase in microbial biomass with the decrease in the water table, accompanied with changes in species level.

Wetlands contain about $12 \%$ of the global carbon pool, playing an important role in the global carbon cycle (IPCC 2014). Large areas of hydric soils have been impacted by agricultural conversion, drainage or climate change. Restoring degraded hydric soils and ecosystems and conservation of existing wetlands has a high potential for sequestrating soil carbon. The most important steps for restoration and conservation of the wetlands are the reduction of stressors causes by human activities which can increase the resiliency of habitats and species to the effects of climate change and variability (Erwin, 2009), sustaining convenient species composition, ceasing agriculture and reestablishment of wetland hydrology (Rosenthal, 2003) by raising water table above the crucial when respiration becomes being limited by water saturation of the soil.

Our results shows that it is very important to include soil water conditions in models estimating $\mathrm{CO}_{2}$ efflux from wetland ecosystems. The steepest decline of soil $\mathrm{CO}_{2}$ efflux was observed with the increasing water table above the soil depth $3 \mathrm{~cm}$. Therefore, this water table depth is crucial for soil $\mathrm{CO}_{2}$ efflux models at this site as $\mathrm{CO}_{2}$ production in the soil profile begins quickly "switching off" due to anaerobic soil conditions.

Acknowledgements. This work was supported by the Ministry of Education, Youth and Sports of CR within the National Sustainability Program I (NPU I), grant number LO1415. Special thanks to the technician Stanislav Stellner for technical cooperation and realization of proper measurements. Authors wish also to thank Dr. Ryan Patrick McGloin, Ph.D., for revising the English language of this manuscript.

\section{REFERENCES}

[1] Alm, J., Shurpali, N.J., Tuittila, E.-S., Laurila, T., Maljanen, M., Saarnio, S., Minkkinen, K. (2007): Methods for determining emission factors for the use of peat and peatlands flux measurements and modelling. - Boreal Environment Research 12: 85-100.

[2] Altor, A.E., Mitsch, W.J. (2008): Methane and carbon dioxide dynamics in wetland mesocosms: Effects of hydrology and soils. - Ecological Applications 18: 1307-1320.

[3] Aubinet, M., Papale, D., Vesala, T. (2012): Eddy Covariance: A Practical Guide to Measurement and Data Analysis. - Springer, Dordrecht.

[4] Baldocchi, D.D. (2003): Assessing the eddy covariance technique for evaluating carbon dioxide exchange rates of ecosystems: past, present and future. Review. - Global Change Biology 9: 479- 492.

[5] Bonnett, S.A.F., Ostle, N., Freeman, C. (2006). Seasonal variations in decomposition processes in a valley-bottom riparian peatland. - Science of the Total Environment 370: 561-573. 
[6] Chamindu Deepagoda, T.K.K., Elberling, B. (2015): Characterization of diffusivitybased oxygen transport in Arctic organic soil. - European Journal of Soil Science 66: 983-991.

[7] Chimner, R.A., Cooper, D.J. (2003). Influence of water table levels on $\mathrm{CO}_{2}$ emissions in a Colorado subalpine fen: an in situ microcosm study. - Soil Biology \& Biochemistry 35: 345-351.

[8] Bubier, J.L., Crill, P.M., Moore, T.R., Savage, K., Varner, R.K. (1998): Seasonal patterns and controls on net ecosystem $\mathrm{CO}_{2}$ exchange in a boreal peatland complex. Global Biogeochemical Cycles 12: 703-714.

[9] Davidson, E.A., Janssens, I.A., Luo, Y.Q. (2006): On the variability of respiration in terrestrial ecosystems: moving beyond $\mathrm{Q}_{10}$. - Global Change Biology 12: 154-164.

[10] Dusek, J., Cizkova H., Czerny, R. Taufarova, K., Smidova, M., Janous, D. (2009): Influence of summer flood on the net ecosystem exchange of $\mathrm{CO} 2$ in a temperate sedge-grass marsh. - Agriculture and Forest Meteorology 149: 1524-1530.

[11] Dusek, J., Cizkova, H., Stellner, S., Czerny, R., Kvet, J. (2012a): Fluctuating water table affects gross ecosystem production and gross radiation use efficiency in a sedgegrass marsh. - Hydrobiologia 692: 57-66.

[12] Dusek, J., Stellner, S., Komarek, A. (2012b): Long-term air temperature changes in a Central European sedge-grass marsh. - Ecohydrology DOI: 10.1002/eco.1256.

[13] Erwin, K L. (2009): Wetlands and global climate change: the role of wetland restoration in a changing world. - Wetlands Ecology and Management 17: 71-84.

[14] Gazda, J. (1983): Vývoj, struktura a primární produkce metlicových luk (StellarioDeschampsietum Freitag 1957) na Mokrých loukách u Třeboně (Development, structure and primary production of the tufted hair-grass meadows (StellarioDeschampsietum Freitag 1957) in the "Wet Meadows" near Třeboň). - In: Jeník, J., Květ, J. (eds.) Studie zaplavovaných ekosystémů u Třeboně, Studie ČSAV 1983/4. Academia: Praha: 88-92.

[15] Goulden, M.L., Munger, J.W., Fan, S.M., Daube, B.C., Wofsy, S.C. (1996). Exchange of carbon dioxide by a deciduous forest: response of interannual climate variability. Science 271: 1576-1578.

[16] Greenwood, D. J. (1961): The effect of oxygen concentration on the decomposition of organic materials in soil. - Plant and Soil 14: 360-376.

[17] Hogg, E.H., Lieffers, V.J., Wein, R.W. (1992): Potential carbon losses from peat profiles - effects of temperature, drought cycles, and fire. - Ecological Applications 2: 298-306.

[18] Holubickova, B. (1959): Př́śsp̌vek ke studiu rašeliništní vegetace. I. Mokré louky u Třeboně (A contribution to the study of moorland vegetation. I. Mokré louky near Třeboň). - Sborník Vysoké Školy Zemědělské v Praze: 257-285.

[19] Inglett, P. W., Reddy, K. R., Corstanje R. (2005): Anaerobic Soils. - In: Hillel, D. (ed.) Encyclopedia of Soils in the Environment. Academic Press. 72-78.

[20] Inglett, K.S., Inglett, P.W., Reddy, K.R., Osborne, T.Z. (2012): Temperature sensitivity of greenhouse gas production in wetland soils of different vegetation. -Biogeochemistry 108: 77-90.

[21] IPCC (2014). Climate change 2014: synthesis report. A contribution of Working Groups I, II and III to the Fifth Assessment Report of the Intergovernmental Panel on Climate Change (Core Writing Team, Pachauri R.K., Meyer L.A., eds.). - IPCC, Geneva, Switzerland, pp. 151.

[22] Jaatinen, K., Laiho, R., Vuorenmaa, A., del Castillo, U., Minkkinen, K., Pennanen, T., Penttilä, T., Fritze, H. (2008): Responses of aerobic microbial communities and soil respiration to water-level drawdown in a northern boreal fen. - Environmental Microbiology 10: 339-353. 
[23] Jassal, R., Black, A., Novak, M., Morgenstern, K., Nesic, Z., Gaumont-Guay, D. (2005). Relationship between soil $\mathrm{CO}_{2}$ concentrations and forest-floor $\mathrm{CO}_{2}$ effluxes. Agricultural and Forest Meteorology 130: 176-192.

[24] Jenik, .J, Květ, J. (1983): Studie zaplavovaných ekosystémů u Třeboně (Ecological study of inundated ecosystems near Třeboň, South Bohemia, Czechoslovakia). - Studie ČSAV 1983/4, Academia, Praha.

[25] Jenik, J., Kurka, R., Husak, S. (2002): Wetlands of the Třeboň basin biosphere reserve in the Central European context. - In: Květ, J., Jeník, J., Soukupová, L. (eds.) Freshwater Wetlands and Their Sustainable Future. A Case Study of the Třeboň Basin Biosphere Reserve, UNESCO, Paris and The Parthenon Publishing Group: Boca Rayton: 11-18.

[26] Jimenez, K.L., Starr, G., Staudhammer, C.L., Schedlbauer, J.L., Loescher, H.W., Malone, S.L., Oberbauer, S.F. (2012): Carbon dioxide exchange rates from short- and long-hydroperiod Everglades freshwater marsh. - Journal of Geophysical ResearchBiogeosciences 117: DOI: 10.1029/2012JG002117.

[27] Knorr, K.H., Oosterwoud, M.R., Blodau, C. (2008): Experimental drought alters rates of soil respiration and methanogenesis but not carbon exchange in soil of a temperate fen. - Soil Biology \& Biochemistry 40: 1781-1791.

[28] Kutsch, W., Bahn, M., Heinemeyer, A. (2009): Soil Carbon Dynamics. Cambridge University Press, Cambridge.

[29] Kuzyakov, Y. (2006): Sources of $\mathrm{CO}_{2}$ efflux from soil and review of partioning methods. - Soil Biology \& Boichemistry 38: 425-448.

[30] Květ, J., Jeník, J., Soukupová, L. (2002): Freshwater Wetlands and Their Sustainable Future. A Case Study of the Třeboň Basin Biosphere Reserve, Czech Republic. - The Parthenon Publishing Group. Paris.

[31] Lafleur, P.M., Moore, T.R., Roulet, N.T., Frolking, S. (2005): Ecosystem respiration in a cool temperate bog depends on peat temperature but not water table. - Ecosystems 8: $619-629$.

[32] Livingston, G.P., Hutchinson, G.L. (1995): Enclosure--based measurement of trace gas exchange: applications and sources of error. - In: Matson P.A., Harriss, R.C. (eds.) Biogenic Trace Gases: Measuring Emissions from Soil and Water. Cambridge, Blackwell Science: $14-50$.

[33] Lloyd, C.R. (2006): Annual carbon balance of a managed wetland meadow in the Somerset Levels, UK. - Agricultural and Forest Meteorology 138: 168-179.

[34] Lloyd, J., Taylor, J.A. (1994): On the temperature dependence of soil respiration. Functional Ecology 8: 315-323.

[35] Longdoz, B., Yernaux, M., Aubinet, M. (2000): Soil $\mathrm{CO}_{2}$ efflux measurements in a mixed forest: impact of chamber distances, spatial variability and seasonal evolution. Global Change Biology 6: 907-917.

[36] Matson, P.A., Harriss, R.C. (1995): Biogenic trace gases: measuring emissions from soil and water. - Blackwell Science, Oxford.

[37] Oechel, W.C., Vourlitis, G.L., Hastings, S.J., Ault, R.P., Bryant, P. (1998). The effects of water table manipulation and elevated temperature on the net $\mathrm{CO}_{2}$ flux of wet sedge tundra ecosystems. - Global Change Biology 4: 77-90.

[38] Pavelka, M., Acosta, M., Marek, M.V., Kutsch, W., Janous, D. (2007): Dependence of the $\mathrm{Q}_{10}$ values on the depth of the soil temperature measuring point. - Plant and Soil 292: 171-179.

[39] Phillips, C.L., Nickerson, N., Risk, D., Bond, B.J. (2011): Interpreting diel hysteresis between soil respiration and temperature. - Global Change Biology 17: 515-527.

[40] Phillips, S.C., Varner, R.K., Frolking, S., Munger, J.W., Bubier, J.L., Wofsy, S.C., Crill, P.M. (2010): Interannual, seasonal, and diel variation in soil respiration relative to ecosystem respiration at a wetland to upland slope at Harvard Forest. - Journal of Geophysical Research-Biogeosciences 115. 
[41] Ponnamperuma, F.N. (1972): The chemistry of submerged soils. - Academic Press New York.

[42] Prach, K., 1993: Vegetational changes in a wet meadow complex, South-Bohemia, Czech Republic. - Folia Geobotänica and Phytotxonomica 28: 1-13.

[43] Prach, K., Soukupova, L. (2002). Alterations in the Wet Meadows vegetation pattern. In: Kvet, J., Jenik, J., Soukupova, L. (eds.) Freshwater Wetlands and their sustainable future. A Case Study of the Třeboň Basin Biosphere Reserve, Czech Republic. CRC Press, Boca Raton: 243-254.

[44] Prach, K. (2008): Vegetation Changes in a wet meadow complex during the past halfcentury. - Folia Geobotanica 43: 119-130.

[45] Pumpanen, J., Kolari, P., Ilvesniemi, H., Minkkinen, K., Vesala, T., Niinisto, S., Lohila, A., Larmola, T., Morero, M., Pihlatie, M., Janssens, I.A., Yuste, J.C., Grunzweig, J.M., Reth, S., Subke, J.A., Savage, K., Kutsch, W., Ostreng, G., Ziegler, W., Anthoni, P.M., Lindroth, A., Hari, P. (2004): Comparison of different chamber techniques for measuring soil $\mathrm{CO}_{2}$ efflux. - Agriculture and Forest Meteorology 123: 159-176.

[46] R Development Core Team (2011): R: A Language and Environment for Statistical Computing. $\mathrm{R}$ Foundation for Statistical Computing, Vienna, Austria. URL http://www.R-project.org. ISBN 3-900051-07-0.

[47] Reddy, R.R., DeLaune, R.D. (2008): Biogeochemistry of Wetlands: Science and Applications. - CRC Press: Boca Raton, USA.

[48] Reichstein, M., Falge, E., Baldocchi, D., Papale, D., Aubinet, M., Berbigier, P., Bernhofer, C., Buchmann, N., Gilmanov, T., Granier, A., Grunwald, T., Havrankova, K., Ilvesniemi, H., Janous, D., Knohl, A., Laurila, T., Lohila, A., Loustau, D., Matteucci, G., Meyers, T., Miglietta, F., Ourcival, J.M., Pumpanen, J., Rambal, S., Rotenberg, E., Sanz, M., Tenhunen, J., Seufert, G., Vaccari, F., Vesala, T., Yakir, D., Valentini, R. (2005): On the separation of net ecosystem exchange into assimilation and ecosystem respiration: review and improved algorithm. - Global Change Biology 11: 1424-1439.

[49] Reth, S., Godecke, M., Falge, E. (2005): $\mathrm{CO}_{2}$ efflux from agricultural soils in eastern Germany - comparison of a closed chamber system with eddy covariance measurements. - Theoretical and Applied Climatology 80: 105-120.

[50] Riveros-Iregui, D.A., Emanuel, R.E., Muth, D.J., McGlynn B.L., Epstein, H.E., Welsch, D.L., Pacific, V.J., Wraith, J.M. (2007): Diurnal hysteresis between soil $\mathrm{CO}_{2}$ and soil temperature is controlled by soil water content. - Geophysical Research Letters 34.

[51] Rosenthal, G. (2003): Selecting target species to evaluate the success of wet grassland restoration. - Agriculture Ecosystems \& Environment 98: 227-246.

[52] Silvola, J., Alm, J., Ahlholm, U., Nykanen, H., Martikainen, P.J. (1996): $\mathrm{CO}_{2}$ fluxes from peat in boreal mires under varying temperature and moisture conditions. - Journal of Ecology 84: 219-228.

[53] Sierra, J., Renault, P. (1998): Temporal pattern of oxygen concentration in a hydromorphic soil. - Soil Science Society of America Journal 62: 1398-1405.

[54] Subke, J.A., Bahn, M. (2010): On the 'temperature sensitivity' of soil respiration: Can we use the immeasurable to predict the unkonwn? - Soil Biology \& Biochemistry 42: $1653-1656$.

[55] Taylor, K.E. (2001): Summarizing multiple aspects of model performance in a single diagram. - Journal of Geophysical Research 106: 7183-7192.

[56] Tufekcioglu, A., Raich, J.W., Isenhart, T.M., Schultz, R.C. (1998): Fine root dynamics, coarse root biomass, root distribution, and soil respiration in a multispecies riparian buffer in Central Iowa, USA. - Agroforestry Systems 44: 163-174.

[57] Vicca, S., Fivez, L., Kockelbergh, F., Van Pelt, D., Segers, J.J.R., Meire, P., Ceulemans, R., Janssens,I.A. (2009): No signs of thermal acclimation of heterotrophic respiration from peat soils exposed to different water levels. - Soil Biology \& Biochemistry 41: 2014-2016. 
[58] Wang, Z.H., Bou-Zeid, E. (2012): A novel approach for the estimation of soil ground heat flux. - Agricultural and Forest Meteorology 154: 214-221.

[59] Xu, L.K., Baldocchi, D.D., Tang, J.W. (2004): How soil moisture, rain pulses, and growth alter the response of ecosystem respiration to temperature. - Global Biogeochemical Cycles 18.

[60] Yang, J., Liu, J., Hu, X., Li, X., Wang, Y., Li, H. (2013): Effect of water table level on $\mathrm{CO}_{2}, \mathrm{CH}_{4}$ and $\mathrm{N}_{2} \mathrm{O}$ emissions in a freshwater marsh of Northeast China. - Soil Biology and Biochemistry 61: 52-60. 